TOMASZ FLASIŃSKI

\title{
CZARNOKSIĘŻNIK Z DOLAROWEJ KRAINY, CZYLI RZECZ O INTERPRETACJI ŹRÓDEŁ
}

W 1964 r. rozpoczęła się jedna z najdziwniejszych dyskusji w nauce amerykańskiej, trwająca 30 lat z okładem i angażująca historyków gospodarki, ekonomistów, literaturoznawców, a nawet socjologów. Nie dotyczyła ona żadnej kontrowersyjnej pracy naukowej, lecz... powieści dla dzieci. Mowa o Czarnoksiężniku ze Szmaragdowego Grodu (The Wonderful Wizard of $\mathrm{Oz}$ ) Lymana Franka Bauma ${ }^{1}$. Powieść tę próbowano analizować na różne sposoby, ale tylko jedna z interpretacji znalazła naukowe uznanie i została w pewnym momencie powszechnie zaakceptowana jako kanoniczna. Sformułował ją Henry M. Littlefield, sugerujacy, by czytać Czarnoksiężnika jako alegoryczny obraz USA pod koniec XIX w., ze szczególnym uwzględnieniem historii Partii Populistycznej i kampanii wyborczej w 1896 r.

By umożliwić zrozumienie tej tezy, niezbędne jest przypomnienie niektórych problemów determinujacych życie społeczne Stanów Zjednoczonych w tym okresie. Piszący te słowa nie rości sobie w niniejszej pracy pretensji do ich wyczerpujacego przedstawienia (musiałaby ona bowiem przybrać formę grubej książki), a jedynie sygnalizuje, wraz ze

\footnotetext{
${ }^{1}$ Podczas pisania niniejszej pracy pewnym problemem okazała się kwestia polskiego przekładu powieści Bauma. Klasyczne tłumaczenie S. Wortmanowej (Czarnoksiężnik ze Szmaragdowego Grodu, Warszawa 1990), choć wielokrotnie celniejsze od pozostałych, dość mocno zniekształca oryginał, tak że niektórych z przywoływanych w niniejszym tekście cytatów nie ma tam w ogóle. Pozostałe trzy, stosunkowo nowe (A. Rajcy, M. Pawlik-Leniarskiej i P. Łopatki) również mają jednak wady i nie sposób przyjąć któregokolwiek z nich za wzorcowe. Ostatecznie zdecydowałem się zachować tłumaczenia nazw w utrwalonej wśród czytelników wersji Wortmanowej (np. Kalidahy, a nie Kalidy, Szmaragdowy Gród, a nie Szmaragdowe Miasto), a cytaty przełożyłem samodzielnie z wersji angielskiej (http://www.gutenberg.org/etext/55). Z tego powodu nie podaje przy nich stron w jakimkolwiek wydaniu, a jedynie rozdziały.
} 
wskazówkami bibliograficznymi, węzłowe zagadnienia stanowiące tło wywodów Littlefielda i jego kontynuatorów².

$\mathrm{Na}$ pierwsze miejsce wysuwa się pauperyzacja farmerów, spowodowana wzrostem produkcji rolnej i spadkiem cen zboża. Efektem tego procesu stały się różne formy oddolnej organizacji mieszkańców stanów rolniczych (ruch grangerów, Związek Południowy i Północny), a wreszcie uformowanie alternatywnej wobec istniejącego układu partii politycznej, tzw. populistów (National People Party), która obok obrony interesów rolników formułowała szersze postulaty przebudowy państwa, idące w kierunku zwiększonej centralizacji i nacjonalizacji pewnych gałęzi przemysłu (np. komunikacji i łączności), dotąd kontrolowanych przez wielki kapitał, oskarżany o manipulowanie cenami ${ }^{3}$. Innym istotnym zjawiskiem był kryzys przemysłu i handlu w 1893 r., owocujący 20-procentowym bezrobociem oraz falą strajków (np. „marsz na Waszyngton" tzw. armii Coxeya) i wzrostem niechęci do wielkich korporacji, oskarżanych o wyzysk, tolerowanie nieludzkich warunków pracy oraz łamanie praw pracowniczych ${ }^{4}$. Trzecim szeroko dyskutowanym zagadnieniem był spór o srebrnego dolara. W 1873 r. Kongres USA zdecydował o odejściu od systemu bimetalicznego (relacja srebra do złota ustalona na poziomie 16:1) i oparciu systemu monetarnego na złocie ${ }^{5}$. Bezpośrednim powodem tego kroku był krótkotrwały niedobór srebra. Jednak odkrycie nowych złóż tego metalu spowodowało, że ostatecznie jego cena znacznie spadła. Za powrotem do bimetalizmu przy zachowaniu starej relacji optowało potężne lobby związane z górniczymi stanami Zachodu oraz zadłużeni farmerzy, liczący na wzrost cen płodów

${ }^{2}$ Poświęcona tym problemom literatura w języku polskim jest dość uboga. Z ogólnych opracowań warto polecić: K. Michałek, Na drodze ku potędze. Historia Stanów Zjednoczonych Ameryki 1861-1945, Warszawa 1991, s. 85-122. W Historii Stanów Zjednoczonych Ameryki, t. 3: 1848-1917, red. W. Nugent, H. Parafianowicz, Warszawa 1995, znajduja się dwa przydatne artykuły: P.N. Limerick, Amerykański Zachód 1848-1917, s. 93-122; D.R. Goldfield, Rozwój miast i przemystu w latach 1850-1920, s. 151-184. Natomiast z Historii Stanów Zjednoczonych Ameryki H. Brogana (tłum. E. Macauley, Wrocław 2004) należy korzystać ostrożnie, jej fragment dotyczący tego okresu (s. 449-478) łączy w sobie nieco cennych refleksji z pochopnymi, ferowanymi niekiedy na wyrost ocenami i agresywnym językiem.

${ }^{3}$ Klasyczna monografia ruchu: L. Goodwin, The Populist Moment. A Short History of Agrarian Revolt in America, Oxford 1978.

${ }^{4}$ Literatura poświęcona kryzysowi jest olbrzymia, najnowsza godna polecenia publikacja to: D. Steeples, D.O. Whitten, Democracy in Desperation. The Depression of 1893, Westport 1998.

${ }^{5} \mathrm{O}$ odbiorze tego wydarzenia najlepiej mówi fakt, że utrwaliło się ono w historii jako The Crime of 1873 , taki też tytuł ma poświęcony mu znany tekst Miltona Friedmana opublikowany w „Journal of Political Economy” 98, 1990, s. 1159-1194. 
rolnych, inflację i związany z nią łatwy dostęp do tanich kredytów. Pomysł popierała większość demokratów i niemała część republikanów oraz mniejsza partia „zielonych”, ugrupowanie głównie farmerskie (nazwa pochodzi od wypuszczonych na wielka skalę podczas wojny secesyjnej papierowych dolarów - „greenbacków”, które chcieli oni utrzymać w obiegu mimo znacznego zdewaluowania). W tej sytuacji grupy przeciwne projektowi - zwłaszcza elity biznesu i przemysłu oraz liczni zwłaszcza we wschodnich stanach robotnicy, przeciwnicy wzrostu cen i spadku wartości pieniądza - znalazły się na razie w defensywie.

W 1878 r. mimo weta prezydenta Hayesa Kongres uchwalił Bland-Allison Act, zgodnie z którym skarb państwa co miesiąc miał kupować po cenach rynkowych srebro o wartości 2-4 mln dolarów i wybijać z niego monety, trzymając się starej relacji srebra do złota, wynoszącej $16: 1^{6}$. Przy okazji pojawiła się idea ogólnoświatowego systemu monetarnego, który wyeliminowałby spekulację metalami szlachetnymi na rynkach: „natychmiast po promulgowaniu niniejszej ustawy Prezydent winien wezwać rządy krajów tworzących tak zwaną Unię Łacińską a także rządy tych z pozostałych krajów europejskich, które uzna za stosowne - do wzięcia udziału we wspólnej ze Stanami Zjednoczonymi konferencji mającej na celu przyjęcie powszechnego kursu złota wobec srebra, mając na celu zaprowadzenie w międzynarodowym użytku pieniądza bimetalicznego oraz zapewnienie, że wartość tych dwóch kruszców wobec siebie pozostanie niezmienna"7. Administracja Hayesa (i następnych prezydentów), nie mogąc zablokować ustawy, osłabiała jej działanie, starając się nie przekroczyć minimalnego progu zakupów, tzn. owych 2 mln miesięcznie. Było to zbyt mało tak dla farmerów, jak i dla lobby górniczego (miesięczne wydobycie srebra w USA było wówczas ponad dwa razy większe). W reakcji na to w 1890 r. uchwalono Sherman Silver Purchase Act ${ }^{8}$. Odtąd co miesiąc skupować miano srebro o wartości 4,5 mln dolarów, płacąc za nie wymyślonymi w $1878 \mathrm{r}$. „Srebrnymi certyfikatami”, czyli banknotami wymienialnymi na złoty

${ }^{6}$ Tekst ustawy w: The Statutes at Large of the United States of America, t. 20, $45^{\text {th }}$ Congress, Session II, s. 25-26 (http://www.historycentral.com/Documents/Brandallison.html, 21 XI 2011).

${ }^{7}$ Łacińska Unia Monetarna (ŁUM) - powstała w 1865 r. unia walutowa europejskich państw bimetalistycznych, przyjmujacca za parytet franka germinal, ustanawiająca równość walut krajów członkowskich i relację cen srebra do złota na poziomie 15,5:1. W okresie, o którym mowa, w praktyce poszczególne kraje odchodziły od tych założeń. Por. W. Morawski, Powszechna historia pieniadza i bankowości, Warszawa 2002, s. 99-102.

8 Tekst ustawy w: The Statutes at Large of the United States of America, t. 26, $51^{\text {th }}$ Congress, s. 289-291. 
lub srebrny bilon ${ }^{9}$. W efekcie tych działań do 1893 r. połowa zapasów złota odpłynęła ze skarbu państwa do prywatnych posiadaczy. W tymże roku przerażony kryzysem prezydent Cleveland - demokrata i zwolennik nie tyle Gold Standard, co ograniczenia bimetalizmu - skłonił Kongres do uchylenia ustawy Shermana ${ }^{10}$.

Wyżej wymienione problemy stały się kluczowymi kwestiami w kampanii wyborczej w 1896 r. Niepopularność posunięć gospodarczych Clevelanda sprawiła, że na konwencji demokratów przegrał on walkę o nominację $\mathrm{z}$ Williamem Jenningsem Bryanem, dotąd mało znanym 36-letnim senatorem z Nebraski, który zrobił na zgromadzonych ogromne wrażenie mową oskarżająca finansistów o chęć „przybicia człowieka pracy do krzyża ze złota”, tzn. forsowanie Gold Standard kosztem zwykłych Amerykanów ${ }^{11}$. Dało mu to nie tylko nominację demokratów, ale i wsparcie populistów, których kilkunastu przedstawicieli zdążyło już znaleźć się w Kongresie. Bryan w dużej mierze podzielał program tych ostatnich, obiecujac np. szeroko zakrojone wsparcie rządowe dla farmerów. Co więcej, na konwencji republikanów doszło do rozłamu. Delegaci górniczych stanów zachodnich, zagrożeni utratą wyborców, założyli nową partię - „Srebrnych Republikanów”, która poparła Bryana. Również demokraci podzielili się w sprawie Gold Standard. Pewna liczba jego zwolenników opuściła szeregi partii, tworząc Narodową Partię Demokratyczną (z własnym kandydatem) ${ }^{12}$. W ten sposób wybory prezy-

${ }^{9} \mathrm{Na}$ temat ekonomicznej sytuacji w tym czasie zob. H.U. Faulkner, Politics, Reform, and Expansion, 1890-1900, New York 1959; R. Jensen, The Winning of the Midwest. Social and Political Conflict, 1888-1896, Chicago 1971.

${ }^{10} \mathrm{O}$ tej ostatniej sprawie zob. K.S. Hoffman, „Going Public” in the Nineteenth Century. Grover Cleveland's Repeal of the Sherman Silver Purchase Act, „Rhetoric and Public Affairs" 5, 2002, s. 57-77. O samym Clevelandzie zob. najnowsza, godna polecenia (acz niewielka) biografię: H. Graff, Grover Cleveland, New York 2002, choć wielu amerykańskich historyków do dziś uważa, że wciąż nie powstało nic lepszego od nagrodzonej Pulitzerem pracy A. Nevinsa, Grover Cleveland. A Study in Courage, New York 1932. Więcej nt. samego sporu o srebro zob. P.M. Garber, V.U. Grilli, The Belmont-Morgan Syndicate as an Optimal Investment Banking Contract, México D.F. 1985 (Serie documentos de trabajo II/1985, El Colegio de México), (http://centros.colmex. mx/cee/images/horizontal/publicaciones/dt/1985/garber-grilli-1985.pdf, 21 XI 2011).

${ }^{11}$ Najobszerniejsza biografia Bryana: P. Coletta, William Jennings Bryan - omawianego okresu dot. t. 1: Political Evangelist (1860-1908), Lincoln 1964. Warto też polecić biografię najnowsza, dobrze ocenioną w środowisku naukowym i przystępnie napisana: M. Kazin, A Godly Hero. The Life of William Jennings Bryan, New York 2006. Tekst mowy w: P. Coletta, dz. cyt., s. 140-141 (jeżeli nie zaznaczono inaczej, tłum. T.F.).

${ }^{12}$ O Narodowej Partii Demokratycznej zob. D.T. Beito, L.R. Beito, Gold Democrat and the Decline of Classical Liberalism 1896-1900, „Independent Review” 4, 2000 (Spring), s. 555-575. 
denckie stały się de facto wyborem między bimetalizmem (zwolenników Bryana powszechnie nazywano silverites - „srebrniacy”) a złotem. Za tym ostatnim optował republikański nominat William McKinley, sceptyczny wobec bimetalizmu i związanej z nim inflacji. Dzięki wsparciu podzielajacych to podejście elit biznesowych USA Mark Hanna, energiczny menedżer kampanii McKinleya, zebrał na nią ogromne środki ${ }^{13}$. Oficjalnie było to 3,5 mln dolarów, rzeczywista kwota szacowana jest na mniej więcej 10 do $16 \mathrm{mln}$. To pozwoliło mu posłużyć się na wielką skalę mass mediami, by promować swego kandydata. Dla poparcia sprawy republikanów wydrukowano np. 275 różnych pamfletów w łącznej liczbie 120 mln kopii, nie tylko po angielsku, polsku czy włosku, ale i w takich językach jak jidysz czy szwedzki. Przemówienia McKinleya i jego stronników zdominowały fale radiowe i szpalty znacznej części gazet ${ }^{14}$. Bryan, nie mając takich pieniędzy, obrał inną taktykę: wykorzystując swój talent oratorski, przemierzył Stany wzdłuż i wszerz koleja, by organizować wiece poparcia i przemawiać do wyborców. W ciąu trzech miesięcy wygłosił ok. 600 mów (sic! ${ }^{15}$. Ostatecznym zwycięzca okazał się McKinley, o ile jednak wśród elektorów uzyskał znacząca większość (271 wobec 176 głosujących na Bryana), to wśród wyborców jego przewaga wyniosła tylko około pół miliona głosów na prawie $14 \mathrm{mln}$ głosujących. Szalę na rzecz McKinleya przeważyli robotnicy ze Wschodniego Wybrzeża, do których retoryka Bryana nie przemówiła, a także bardzo już liczni imigranci, skuszeni hasłem „porozumienia ponad etnicznymi podziałami”. Hasło Bryana „16 do 1” (uncji srebra do uncji złota) dało mu jednak olbrzymią większość wśród farmerów (z wyłączeniem najzamożniejszych) i w wielu innych środowiskach ${ }^{16}$.

Ci sami kandydaci stanęli przeciw sobie w wyborach w 1900 r., przy czym Bryan stał się wówczas oficjalnym nominatem nie tylko demokratów, lecz i populistów. Na krótko przed rozpoczęciem kampanii wyborczej McKinley przeforsował Gold Standard Act, opierający system

${ }^{13}$ Nowoczesna biografia Hanny niestety nie istnieje. Warto za to sięgnąć do pracy jego bratanka: J.P. Rhodes, The McKinley and Roosevelt Administrations, 1897-1909, New York 1922, s. 1-17, 35-37, 140-141.

${ }^{14}$ Dane za: M. Josephson, The Bryan Campaign, w: William Jennings Bryan and the Campaign of 1896, red. G.F. Whicher, Boston 1953, s. 50.

15 Tamże, s. 43.

${ }^{16}$ O kampanii wyborczej w 1896 r. zob. P.W. Glad, McKinley, Bryan, and the People, New York 1964; S.L. Jones, The Presidential Election of 1896, Madison 1964; J.A. Barnes, Myths of the Bryan Campaign, „Mississippi Valley Historical Review” 34, 1947, nr 12; P. Coletta, dz. cyt., s. 98-212. Na temat nowatorstwa metod prowadzenia tej kampanii por. W.D. Harpine, From the Front Porch to the Front Page. McKinley and Bryan in the 1896 Presidential Campaign, College Station 2005. 
monetarny USA na złocie (choć jego ostatni artykuł sugerował, nawiazując do ustawy z 1878 r., że „postanowienia niniejszej ustawy nie maja na celu uniemożliwienia wprowadzenia międzynarodowego bimetalizmu, gdy tylko warunki uczynią stosowną i praktyczną możność jego zabezpieczenia przez wiodace $\mathrm{w}$ handlu narody świata przy zastosowaniu kursu zapewniającego trwałość wzajemnej relacji wartości złota i srebra”, co jednak uznawano raczej za pustą deklarację, zważywszy stopniowe odchodzenie od bimetalizmu przez kraje europejskie ${ }^{17}$ ). Ważnymi elementami kampanii Bryana w wyborach w 1900 r. były: postulat obalenia tej ustawy oraz krytyka „imperializmu” McKinleya, który niedawno zadecydował o aneksji Filipin wbrew woli ich mieszkańców. Ogólna poprawa sytuacji gospodarczej, która przekonała wiele osób do Gold Standard, i umiejętne odwołanie się przez republikanów do patriotycznych nastrojów, rozbudzonych w kraju wojną z Hiszpania, przyniosło jednak McKinleyowi jeszcze wyższy wynik wyborczy niż cztery lata wcześniej ${ }^{18}$.

Latem 1900 r., kilka miesięcy przed ostatecznym rozstrzygnięciem elekcji, na półkach księgarskich pojawiła się nowa książka popularnego od kilku lat autora powieści dziecięcych, byłego kupca, dziennikarza i komiwojażera Lymana Franka Bauma - The Wonderful Wizard of $O z$. Książka ta, opisująca historię dziewczynki z Kansas porwanej trabą powietrzna do magicznej krainy, stała się bestsellerem i doczekała trzynastu kolejnych tomów. Jednym z powodów sukcesu mógł być fakt, że odwołujące się często do amerykańskich realiów dzieło było bliższe krajowemu odbiorcy niż tłumaczenia baśni europejskich. Ale czy owe realia nie wskazywały na głębsze znaczenia powieści?

\section{Interpretacje}

Choć interpretacja Czarnoksiężnika jako alegorycznego przedstawienia programu populistów powstała w 1964 r., gdy Henry M. Littlefield opublikował artykuł The Wizard of Oz. Parable on Populism, jej

${ }^{17}$ Tekst ustawy w: The Statutes at Large of the United States of America, t. 31, $56^{\text {th }}$ Congress, Session I, s. 45-50 (http://www.historycentral.com/Documents/GoldStandard.html, 21 XI 2011).

${ }^{18}$ O kampanii wyborczej w 1900 r. zob. J.W. Bailey Jr., The Presidential Election of 1900 in Nebraska. McKinley over Bryan, „Nebraska History” 4, 1973, nr 54, s. 561-584; E.B. Tompkins, Scilla and Charybdis. The Anti-Imperialist Dilemma in the Election of 1900, „Pacific Historical Review” 2, 1967, nr 36, s. 143-161; P. Coletta, dz. cyt., s. 238-292; N.J. Kent, American in 1900, Armonk 2002. 
korzenie sięgaja $1957 \mathrm{r} .{ }^{19}$ Wtedy to bowiem na rynku pojawiło się wydanie krytyczne powieści, zaopatrzone w sążniste wstępy ${ }^{20}$. Historyk kultury i literatury Russel Nye w eseju An Appreciation analizował samą powieść, natomiast dziennikarz i popularyzator matematyki Martin Gardner napisał szkic biograficzny Bauma The Royal Historian of $O z$, o którym będzie jeszcze mowa. Twierdząc stanowczo (choć raczej mylnie), że kontynuacja The Wonderful Wizard of $\mathrm{Oz}$ - The Marvelous Land of $\mathrm{Oz}$ to satyra na ruch sufrażystek ${ }^{21}$, Nye nie przypisywał części pierwszej alegorycznej interpretacji. Uważał jedynie, że kraina Oz była dla Bauma wizją Ameryki idealnej. Jeden z czytelników jego pracy, licealny nauczyciel historii Henry Littlefield, doszedł jednak do odmiennego wniosku, który rychło opublikował w „American Quarterly": Wizard of $\mathrm{Oz}$ miał jego zdaniem przedstawiać społeczno-polityczną sytuację Stanów Zjednoczonych pod koniec XIX w., ze szczególnym uwzględnieniem historii Partii Populistycznej.

A zatem „droga wybrukowana żółtą kostka” (yellow brick road), której okolica „bywa przyjemna, lecz nieraz jest też mroczna i straszna” (rozdz. 2) to droga oparcia się na złocie, która nie doprowadziła Doroty do zamierzonego celu (tzn. powrotu do Kansas), za to naraziła ją na wiele niebezpieczeństw. Prawdziwym rozwiąaniem jej problemów okazały się Srebrne Trzewiczki, tak jak srebrny dolar, bity w nieograniczonych ilościach, rozwiązałby problemy farmerów. Strach na Wróble, choć ma „głowę wypchana słomą”, jest odważny, wytrzymały i okazuje się wcale niegłupi; symbolizuje więc - wedle Littlefielda - farmerów ze Środkowego Zachodu. Littlefield widział tu ukryta polemikę z Williamem A. White'em, który w 1896 r. opublikował sławny artykuł What's the Matter with Kansas?, sugerując w przewrotny sposób, że problemem Kansas sa sami mieszkańcy - naiwni ignoranci niezdolni do myślenia $^{22}$. Natomiast Zła Czarownica ze Wschodu, która „od wielu lat

${ }^{19}$ H.M. Littlefield, The Wizard of $\mathrm{Oz}$. Parable on Populism, „American Quarterly” 16, 1964, nr 1, s. 47-58.

${ }^{20}$ M. Gardner, R. Nye, L.F. Baum, The Wizard of $\mathrm{Oz} \&$ Who He Was, East Lansing 1957. Wersja ta była wznawiana jeszcze do niedawna, ostatnio w $1994 \mathrm{r}$.

${ }^{21}$ Wydanie polskie: L.F. Baum, W krainie czarnoksięznika Oza, Warszawa 1973 (potem dwa wznowienia). W istocie Baum publikował artykuły popierajace postulaty ruchu, ożenił się z jego aktywną działaczka, w Aberdeen był sekretarzem oddziału Suffrage's Club, w całym zaś cyklu o krainie Oz zdecydowana większość pozytywnych bohaterek to kobiety. The Marvelous Land of $\mathrm{Oz}$ faktycznie wyśmiewa dziewczęta głoszace „kobieca dominację” i odwracajace role przypisane płciom, ale warto tu przywołać rozmowę Stracha na Wróble z mężczyzną w karczmie w rozdz. 7.

${ }^{22}$ W.A. White, What's the Matter with Kansas?, „Emporia”, 15 VIII 1896 (http:// www.kancoll.org/articles/what's_the_matter_with_kansas.html, 21 XI 2011). 
trzymała Manczkinów w niewoli, zmuszając ich, by dla niej pracowali” (rozdz. 2) to rzecz jasna kapitaliści ze Wschodniego Wybrzeża. Co tak wytężona praca robi z ludźmi, pokazuje przykład Blaszanego Drwala. Za sprawa Czarownicy tracił on kolejne części ciała, zastępowane przez kowala metalowymi. Gdy zaś składał się z blachy już cały prócz tułowia (który wraz z sercem również miał wkrótce stracić), „poczuł, że wygrał z Czarownica, i pracował ciężej niż kiedykolwiek" (rozdz. 5). Oto kwintesencja dehumanizacji robotników fabrycznych.

Kolejny towarzysz Doroty, Tchórzliwy Lew, to William J. Bryan we własnej osobie. Jego (Lwa, nie Bryana) autoprezentacja: „Przekonałem się, że jeśli ryknę odpowiednio głośno, każde żywe stworzenie przerazi się i zejdzie mi z drogi” (rozdz. 6) ma być nawiązaniem do zdolności oratorskich niedoszłego prezydenta. Nie wystarczyły one jednak, by w kampanii w 1896 r. przekonać do sprawy demokratów robotników fabrycznych, co ukazano w nieco wcześniejszej scenie: „,[Lew] zaatakował Blaszanego Drwala swymi ostrymi pazurami. Lecz, ku zdziwieniu Lwa, nie zostawiły one najmniejszego śladu na blasze, choć uderzenie przewróciło Drwala na ziemię" (rozdz. 6). Za to tchórzostwo Lwa okazuje się szybko nie aż tak wielkie, skoro już w następnym rozdziale jest on gotów w obronie przyjaciół walczyć do śmierci z Kalidahami. Również Bryan, choć pacyfista i szermierz antyimperializmu, nie głosił tych haseł z tchórzostwa.

Po dotarciu do Szmaragdowego Grodu - Waszyngtonu - bohaterowie zostaja wysłani przez Oza przeciw Złej Czarownicy z Zachodu i walcza ze Skrzydlatymi Małpami, zmuszonymi przez czary do służenia posiadaczowi Złotej Czapki - to zapewne nawiązanie do Indian, których spokojny byt zniszczyła amerykańska żądza pieniądza (przypomnijmy, że właśnie odkrycie złota na terenach Indian spowodowało rugowanie ich stamtąd, której to tendencji nie powstrzymała nawet bitwa pod Little Big Horn). Ostatecznie Dorota rozpuszcza Czarownicę za pomocą wody - „wody, owego cennego dobra tak straszliwie potrzebnego nękanym suszą farmerom Wielkich Równin, które użyte we właściwy sposób może stworzyć rolniczy raj, lub przynajmniej rozpuścić złą czarownicę" ${ }^{23}$. Po ponownym spotkaniu z Ozem okazuje się, że jest to w istocie mały staruszek niezdolny do dokonania czegokolwiek, a co najwyżej do wmówienia innym, że spełnia ich marzenia. Można go więc utożsamić z każdym prezydentem tego okresu (choć pewnie najbardziej z niezdecydowanym Groverem Clevelandem) lub ogólniej uznać za personifikację władzy ukrywającej swoją nieudolność w zaspokajaniu dezyderatów obywateli.

${ }^{23}$ H.M. Littlefield, dz. cyt., s. 56. 
Co ciekawe, Oz pochodzi z Omaha w Nebrasce, a wszak Bryan był senatorem z tego właśnie stanu, w Omaha zaś odbył się kongres założycielski populistów w 1892 r. Ocena tych ostatnich w Czarnoksiężniku jest zatem serdeczna, choć nie bezkrytyczna: powodowani jak najlepszymi intencjami, zwykli Amerykanie występują przeciw złu, jednakże są skazani na porażkę, gdyż politycy to kłamcy i szarlatani.

$\mathrm{Na}$ ile autor tej interpretacji miał do niej dystans? Mimo późniejszych zaprzeczeń, wydaje się, że w niewielkim stopniu: „Baum nigdy nie pozwolił, by spójność alegorii wzięła górę nad osnową dzieła, jakim była dziecięca rozrywka. Lecz raz zauważone alegoryczne intencje autora wydaja się jasne. One to dają głębokie i trwałe zainteresowanie [dziełem] nawet dzieciom, które zaledwie wyczuwaja, że coś jeszcze tkwi pod powierzchnia opowieści. [...] Wypisane tu odniesienia i alegorie maja wprawdzie charakter teoretyczny, lecz sa stanowczo zbyt spójne, by były przypadkowe, co więcej dostarczają one mechanizmu nauczania gwarantującego dotarcie do uczniów w każdym wieku”, pisał Littlefield ${ }^{24}$.

Pogląd ten dość szybko znalazł uznanie wśród innych badaczy. Już w 1971 r. Richard Jensen w swoim studium o środkowych i zachodnich stanach USA pod koniec XIX w. powtórzył i uzupełnił jego interpretację. Pies Doroty, Toto - mały, ale szczekliwy - wziął według niego imię od słowa „teetotaler”, tzn. „zwolennik abstynencji”: ruch prohibicyjny, niezbyt liczny, ale bardzo aktywny, stanowił długo ważną podporę populistów (należał doń sam Bryan). Jensen zauważył też, że „Oz” może stanowić skrót od słowa „ounce” (uncja), co nawiąuje do słynnego sloganu „16 do 1”25. Nie przeszkodził mu w tym fakt, że sam Baum konsekwentnie podawał inną inspirację tej nazwy (od liter $\mathrm{O}-\mathrm{Z}$ wypisanych na segregatorze).

W 1980 r. do podobnych wniosków doszedł historyk literatury Brian Attebery. W swoim studium poświęconym fantastyce amerykańskiej, streściwszy twierdzenia poprzedników, podsuną nową myśl. Uznał, że pierwowzorem Doroty mogła być Mary E. Lease, pochodzacca z Kansas słynna sufrażystka i działaczka populistów, znana z ostrego języ$\mathrm{ka}^{26}$. Badacz ten powoływał się na fakt, że Dorota była bystra, odporna i przewodziła grupie mężczyzn ${ }^{27}$. Lease nosiła też przydomek „Kansas

${ }^{24}$ Tamże, s. 58.

${ }^{25}$ R. Jensen, dz. cyt., s. 282-283.

${ }^{26}$ Choć jej najsłynniejszą wypowiedź, wezwanie do farmerów Kansas: „Raise less corn and more hell!", sfabrykowały media.

${ }^{27}$ B. Attebery, The Fantasy Tradition in American Literature. From Irving to Le Guin, Bloomington 1980, s. 86-87. 
Tornado", co w sposób oczywisty kojarzy się z porwaną przez trąbę powietrzną bohaterką dzieła Bauma ${ }^{28}$.

W latach osiemdziesiątych tezy Littlefielda zyskały sobie status common knowledge. Coraz więcej nauczycieli i wykładowców powtarzało je uczniom jako udowodnione. Znakiem czasów stał się artykuł w piśmie „Social Education” zalecający nauczycielom szkół średnich stosowanie Czarnoksiężnika jako pomocy dydaktycznej podczas lekcji o populistach ${ }^{29}$. W wielu publikacjach $\mathrm{w}$ ogóle już nie wymieniano nazwiska Littlefielda, pisząc o dziele Bauma jako o alegorii: rzecz była przecież udowodniona bez cienia wątpliwości. Stanowiła fakt, a nie pogląd jednego bądź kilku naukowców. David Parker, późniejszy surowy krytyk takiego podejścia do Czarnoksiężnika, sugeruje, że mogła na nim zaważyć po prostu atmosfera epoki: Amerykanie, rozczarowani swoim krajem po aferze Watergate i wojnie wietnamskiej, z zadowoleniem przyjmowali twierdzenie, że ich ulubiona książka kryje w sobie krytykę złych bankierów, imperialistów i polityków ${ }^{30}$. W tym to okresie twierdzenia Littlefielda przebiły się z obiegu akademickiego do świadomości zwykłych ludzi. Popularne artykuły poświęcano im w tak poczytnych pismach jak „Los Angeles Times” czy „Utne Reader”31. Z pewnym opóźnieniem dotarły i do Polski, gdzie ich wielkim orędownikiem stał się Wojciech Morawski ${ }^{32}$.

Tymczasem najszersze rozwinięcie wizji Littlefielda miało dopiero nadejść. W 1990 r. dokonał go Hugh Rockoff, nowojorski wykładowca ekonomii i historii gospodarczej, na łamach prestiżowego „Journal of Political Economy"33. W klimat jego artykułu wprowadza już wstęp: „Gdy patrzy się na opowieść w tym świetle, wiele rzeczy staje się jasnych: prawdziwy powód zaśnięcia Tchórzliwego Lwa na polu trujących maków, tożsamość Czarnoksiężnika Oza, znaczenie dziwnej liczby sal i korytarzy w Szmaragdowym Pałacu czy powód, dla którego Zła Czarownica z Zachodu tak cieszyła się zabrawszy Dorocie jeden z trzewiczków. Zinterpretowany w ten sposób Czarnoksiężnik ze Szmaragdowego

${ }^{28}$ H. Rockoff, The „Wizard of Oz” as a Monetary Allegory, „Journal of Political Economy" 98, 1990, s. 745 .

${ }^{29}$ D.W. Van Cleaf, C.W. Funkhouser, Inquiry, 'Oz' and Populism, „Social Education" 51, 1987, s. 282-283.

${ }^{30}$ D. Parker, The Rise and Fall of The Wonderful Wizard of $\mathrm{Oz}$ as a „Parable on Populism”, „Journal of the Georgia Association of Historians” 15, 1994, s. 51.

${ }^{31}$ Tamże.

${ }^{32}$ W. Morawski, dz. cyt., s. 224; tenże, Kronika kryzysów gospodarczych, Warszawa 2003, s. 93; tenże, Historia finansów wspótczesnego świata od 1900 roku, Warszawa 2008, s. $11-12$.

${ }^{33}$ H. Rockoff, dz. cyt., s. 739-760. 
Grodu staje się potężną pedagogiczną maszynerią. Niewielu studentów finansów i bankowości czy też historii ekonomii zapomni o bitwie między adwokatami srebrnej waluty a obrońcami Gold Standard, gdy cała rzecz wyjaśni im Czarnoksiężnik" ${ }^{34}$.

Autor poczuł się jednak w obowiązku dodać (krótki, trzyakapitowy) fragment skierowany do sceptyków: „Zawsze istnieje niebezpieczeństwo, że tam, gdzie autor umieścił tylko konkretne punkty odniesienia do świata swej opowieści, krytyk zobaczy symbole. [...] Lecz doświadczenie autora może ulec przetworzeniu na sposoby, z których nie do końca zdaje sobie sprawę, nim zostanie ukazane światu w postaci dzieła sztuki. Krytyk może odsłaniać elementy pozostające poza jednoznacznie wyrażonymi intencjami autora. Co więcej, «populistyczną» interpretację podeprzeć można poważnymi dowodami natury pośredniej. Wpadło na nią niezależnie od siebie wielu co bardziej uważnych czytelników. [...] Alegoryczną interpretację opowieści można postrzegać jako coś w rodzaju modelu ekonomicznego. Weryfikacją takiego modelu jest odpowiedź na pytanie: czy za jego pomocą daje się wyjaśnić zjawiska uboczne i pomniejsze? Niniejsza praca jest próba odpowiedzenia na takie pytanie wobec "populistycznej» interpretacji Littlefielda, używając dostępnej nam wiedzy o poglądach populistów na kwestie pieniężne do objaśnienia pomniejszych wątków opowieści Bauma. Fakt, że można to zrobić nie naginajac zbytnio tekstu [with a relatively moderate amount of pushing and pulling] ogromnie wzmacnia wiarygodność «populistycznej» interpretacji” ${ }^{35}$.

„Moderate amount of pushing and pulling” zaczyna się od sugestii, dlaczego akcja rozpoczyna się w Kansas: otóż dlatego, że konwencja demokratów w 1900 r. miała miejsce w Kansas City w stanie Missouri. A że pierwotny tytuł dzieła Bauma brzmiał From Kansas to Fairyland, jest to prosta alegoria drogi z Kansas City do Waszyngtonu.

Większość tej drogi Dorota odbyła przeniesiona trąbą powietrzną. Po polsku trudno oddać urodę frazy, jaka wytłumaczył to Rockoff: „The cyclone is the free silver movement itself. It came roaring out of the West in 1896, shaking the political establishment to its foundations" ${ }^{36}$. Zabił on wszak Złą Czarownicę ze Wschodu, czyli sprzeciwiającego się swobodnej cyrkulacji srebra Grovera Clevelanda. Pozostały po niej Srebrne Trzewiczki. Niestety, Manczkinowie - uciemiężeni mieszkańcy Wschodu - nie znali ich magicznej mocy.

\footnotetext{
${ }^{34}$ Tamże, s. 739.

35 Tamże, s. 752.

${ }^{36}$ Tamże, s. 745-746.
} 
Strach na Wróble, farmer ze Środkowego Zachodu, który mimo „głowy wypchanej słomą" myśli trzeźwo, u Rockoffa staje się reprezentantem „zdrowego chłopskiego rozumu” przeciwstawionego pokrętnym argumentom oderwanych od życia ekonomistów optujących za złotem. W istocie była to częsta dychotomia w propagandzie populistów: furorę w USA robiła w 1896 r. nowela Williama Harveya Coin's Financial School, w której młody ekonomista w prostych słowach zbija argumenty czołowych dziennikarzy USA przeciw srebrnemu dolarowi ${ }^{37}$. Natomiast fakt, że Blaszany Drwal zardzewiał i był niezdolny do pracy, odniesiono do kryzysu w 1890 r., kiedy to wielu robotników ze Wschodniego Wybrzeża straciło pracę. W jednej z późniejszych scen Tchórzliwy Lew zasypia na polu trujacych maków, uśpiony ich zapachem. Wedle Rockoffa chodzi o retorykę antyimperialistyczną (maki i opium nieodmiennie kojarzą się z Azja, gdzie USA od dawna mniej lub bardziej otwarcie działały na rzecz swoich „specjalnych interesów”), która w pewnym momencie zaczęła w wystapieniach Bryana dominować nad kwestia srebrnego dolara. Lwu przychodzi na ratunek Królowa Myszy i jej liczni poddani - niewatpliwie symbol maluczkich, których zajmuje nie wielka polityka, lecz rzeczy bardziej przyziemne, np. ceny kukurydzy. Gdy bohaterowie docieraja do Szmaragdowego Grodu, muszą założyć specjalne okulary, by - jak głosi oficjalna propaganda - nie oślepnąć od blasku szmaragdów; w rzeczywistości właśnie za sprawą zielonych szkieł mieszkańcy przekonani sa, że miasto jest szmaragdowe. Innymi słowy, finansiści z Waszyngtonu zmuszają tych, którymi rządza, do patrzenia na świat przez pryzmat pieniadza. W pałacu Oza Dorota musi przejść przez siedem korytarzy i trzy kondygnacje schodów: siedem i trzy to 73 , a więc rok 1873, gdy Kongres przyją Gold Standard. Gdy następnego dnia ona i jej przyjaciele zostają wezwani przed oblicze Czarnoksiężnika, przechodzą przez wielką salę, gdzie „znajdowało się wiele dam dworu i dworzan w bogatych szatach - nie mieli oni nic do roboty poza rozmawianiem ze sobą" (rozdz. 11) - jak w każdej szanującej się siedzibie rządu. W samym Czarnoksiężniku Ozie Rockoff dopatrzył się Marka Hanny, który potrafił umiejętnie zbudować swój wizerunek „Zwykłego człowieka” pochylonego nad problemami innych, ale nie wywiazywał się z obietnic wyborczych. Rockoff przy okazji zauważył, że Zła Czarownica z Zachodu posłużyła się w swoim czasie Skrzydlatymi Małpami, by wygnać Oza ze swoich domen - a Hanna był właśnie mieszkańcem zachodnich stanów, który zamieszkał na wschodzie (choć nie został wygnany, stąd

\footnotetext{
${ }^{37}$ Książka ta jest w całości dostępna w Internecie: http://coinschool.blogspot.com.
} 
konstatacja: „W tym miejscu Baum wyraźnie odszedł od bezpośredniej alegorii") ${ }^{38}$.

Owa Zła Czarownica z Zachodu to William McKinley we własnej osobie, w przeciwieństwie do Clevelanda wciąż żywotny. Oz każe Dorocie i jej przyjaciołom zmierzyć się z nia, tak jak Hanna odsyłał dziennikarzy i polityków do domu McKinleya w Ohio, by tam rozmawiali bezpośrednio z nim. Czarownica w końcu pokonuje ich dzięki wspomnianym już Skrzydlatym Małpom, które przyzywa za pomoca Złotej Czapki (znów nawiązanie do złota - wiadomo, jak wielkie fundusze świat pieniądza wyłożył na kampanię wyborczą McKinleya). Dorota i pozostali trafiają do jej niewoli, a wraz z nimi przebywa w niej lud Winków, których kolorem jest żółty - dla Rockoffa to „dość czytelne odniesienie do decyzji McKinleya, by odmówić natychmiastowej niepodległości Filipinom"39. Czarownicy po pewnym czasie udaje się podstępem odebrać Dorocie jeden ze Srebrnych Trzewiczków, co symbolizuje meandry polityki ekipy McKinleya wokół kwestii bimetalizmu w kampanii wyborczej w 1896 r. i później. Nie apelowali oni jasno, by poprzestać na złotym dolarze, lecz zgadzali się na powrót do bimetalizmu w wypadku podpisania odpowiednich umów międzynarodowych (populiści uważali to, zresztą słusznie, za mydlenie oczu). Gdy Czarownica rozpuszcza się w wodzie, kowale Winków reperuja Blaszanego Drwala oraz wykuwają mu nową siekierę: trzonek jest w niej złoty, żeleźce zaś „błyszczą się jak polerowane srebro" (rozdz. 13) - ideał populistów, pragnacych harmonijnego współistnienia dwóch metali na rynku pieniężnym.

$\mathrm{Oz}$ - jak Mark Hanna - spełnia obietnice bohaterów w sposób oszukańczy. Gdy odlatuje balonem, Dorota musi udać się z przyjaciółmi do Gladioli Dobrotliwej, by znaleźć jakiś sposób na powrót do domu. Po drodze bohaterowie spotykaja chińskie figurki, które w Krainie $\mathrm{Oz}$ żyją normalnym życiem, ale mogą się potłuc, jeśli podejdą do nich ludzie. To z kolei Rockoff uznał za potępienie udziału wojsk USA w tłumieniu „powstania bokserów”. Ostatecznie Dorota używa Srebrnych Trzewiczków, by zaniosły ją do Kansas, po drodze jednak gubią się one w piaskach pustyni - „tak jak pod koniec ostatniej dekady XIX wieku znikała srebrna waluta. [...] Tak czy owak obserwacja Bauma, że cała sprawa ze srebrem stanie się wkrótce odległym wspomnieniem, okazała się słuszna. W roku 1900 przyjęto ustawę wprowadzającą w USA Gold Standard" 40 .

\footnotetext{
${ }^{38}$ H. Rockoff, dz. cyt., s. 749 .

39 Tamże.

${ }^{40}$ Tamże, s. 752.
} 
Tyle Rockoff. Nie zgodził się z nim Gene Clanton, historyk z Waszyngtonu, który rok później opublikował swoje opus magnum - potężną monografię ruchu populistów. Uznał on, że choć istotnie dzieło Bauma jest alegoria poczynań zwolenników srebra, to nie utożsamiał on ich z populistami ${ }^{41}$. Ci bowiem nawoływali do stworzenia silnego rządu centralnego, co ich sojusznicy w kampanii wyborczej, „srebrni” demokraci, uznawali za niebezpieczny radykalizm. Zatem podczas gdy Zła Czarownica ze Wschodu to istotnie kapitaliści, ta z Zachodu (dysponująca „teleskopowym okiem”, którym widzi wszystko, co się w jej krainie dzieje) symbolizuje właśnie... populizm. Zdaniem Clantona, w Czarnoksiężniku promowany jest nurt reformatorski, ale odżegnujący się od państwa omnipotentnego - przyszły ruch progresywistów.

W tymże samym $1991 \mathrm{r}$. zwolennikom streszczonych powyżej interpretacji zadano miażdżący cios. 20 grudnia na łamach „New York Times" pojawił się list otwarty Michaela Hearna wykazujący na podstawie kwerendy archiwalnej, że Baum nie miał nic wspólnego z przypisywanymi mu przez historyków poglądami.

\section{Czy Baum popierał Bryana?}

Michael P. Hearn, redaktor wydania krytycznego Czarnoksiężika ze Szmaragdowego Grodu (piszący od kilkunastu lat biografię Bauma), zadał sobie trud, by sprawdzić to, od czego należało zacząć, tzn. poglady polityczne autora dzieła.

Littlefield przy tworzeniu swojej konstrukcji korzystał z jedynej szeroko dostępnej biografii, wspomnianego już szkicu Martina Gardnera. Problem polegał na tym, że Gardner, niemający z historią wiele wspólnego, traktował polityczne zapatrywania „Nadwornego Kronikarza Krainy $\mathrm{Oz} "{ }^{42}$ jako temat absolutnie poboczny. W liczącym 25 stron tekście poświęcił im całe dwa zdania: „Poza wzięciem udziału w kilku paradach poparcia dla Williama Jenningsa Bryana, w sferze polityki Baum był równie mało aktywny, co w kwestiach religijnych [tzn. prawie w ogóle - T.F.]. Niemniej jednak niezmiennie głosował na demokratów, a jego sympatia była - jak się zdaje - konsekwentnie po stronie klas pracujacych" ${ }^{43}$. Tę ogólnikową (i w dodatku fałszywa) charaktery-

${ }^{41}$ G. Clanton, Populism. The Humane Preference in America, 1890-1900, Boston 1991, s. $149-150$.

${ }^{42}$ Jak określał się sam Baum.

${ }^{43}$ M. Gardner, The Royal Historian of $\mathrm{Oz}$, w: M. Gardner, R. Nye, L.F. Baum, dz. cyt., s. 29 . 
stykę powieliła niemal bez zmian książkowa biografia Bauma, wydana nieco później m.in. przez jego syna ${ }^{44}$.

$\mathrm{O}$ poglądach politycznych twórcy krainy $\mathrm{Oz}$ w pierwszych trzydziestu latach jego życia (urodził się w 1856) nie wiemy właściwie nic ${ }^{45}$. Gdy stało się oczywiste, że nieśmiały chłopak z głowa w chmurach nie zrobi kariery oficerskiej, ojciec (bogaty biznesmen) wyszedł naprzeciw jego zamiłowaniu do teatru i w 1880 r. wybudował mu własnym kosztem niewielki teatr w Nowym Jorku. Kilka lat później budynek spłoną w trakcie, o ironio, prób do sztuki Bauma Zapałki. Zmusiło to jego właściciela do znalezienia innego sposobu zarabiania na życie. W $1888 \mathrm{r}$. przeniósł się wraz z żoną do Aberdeen w Południowej Dakocie, gdzie zaczał prowadzić sklep, na co miał zdecydowanie za miękkie serce: brak powściagliwości $\mathrm{w}$ dawaniu towaru na kredyt doprowadził go szybko do bankructwa. W styczniu $1890 \mathrm{r}$. nabył za resztki oszczędności lokalną gazetę republikańską „Aberdeen Saturday Pioneer”, którą też sam redagował. Już w kwietniu 1890 r., gdy odbywały się wybory do władz stanowych, Baum zaangażował się w kampanię wyborczą kandydatów republikańskich. Po ich zwycięstwie, 19 kwietnia stwierdził na łamach pisma: „Aberdeen wybrało wybawienie [...] po tym, jak przez niemal rok cierpiało za sprawa niekompetencji demokratycznej administracji”46. Gdy niedługo potem Partia Republikańska w Dakocie stanęła w obliczu rozłamu, wielu jej działaczy przeszło bowiem do nowej Independent Party, Baum irytował się: „Wszyscy jesteśmy członkami jednej wielkiej rodziny, tej, która ocaliła Unię, tej, która dziś stanowi dla narodów świata symbol prosperity - Republikanizmu!" ${ }^{77}$ A program independentów pod wieloma względami przypominał późniejsze hasła populistów...

Choć nie należy to do głównego tematu niniejszej pracy, w obliczu tez Littlefielda o „współczuciu dla Indian” warto przywołać fragment artykułu Bauma z 20 XII 1890 r., napisanego na wieść o śmierci Siedzącego Byka: „Biali są panami kontynentu amerykańskiego na mocy prawa podboju, na mocy sprawiedliwości wynikłej z ucywilizowania -

${ }^{44}$ F.J. Baum, R.P. MacFall, To Please a Child. A Biography of L. Frank Baum, Royal Historian of $\mathrm{Oz}$, Chicago 1961, s. 85, 124.

${ }^{45}$ K.M. Rogers, L.F. Baum: Creator of $\mathrm{Oz}$, New York 2002, s. $1 . \mathrm{O}$ ile nie zaznaczono inaczej, dane biograficzne pochodzą z tej jedynej (jak dotąd) nowoczesnej biografii Bauma.

${ }^{46}$ „Aberdeen Saturday Pioneer”, 19 IV 1890, cyt. za: D. Parker, dz. cyt., s. 54. Jedyny zachowany egzemplarz samej gazety znajduje się (w postaci mikrofilmu) w Alexander Mitchell Library w Aberdeen i był dla mnie niedostępny.

${ }^{47}$ „Aberdeen Saturday Pioneer”, 18 X 1890, cyt. za: tamże. 
a pełne bezpieczeństwo osadnikom z pogranicza zapewnić może całkowite wygubienie nielicznych pozostałych Indian. Czemuż by nie? Ich chwała przeminęła, ich duch upadł, zatarło się ich męstwo; lepiej, by umarli, niż żyli jako żałosne wraki ludzkie, którymi teraz są. Historia zapomni tych spodlonych, przemawiać zaś będzie o dawnych wiekach chwały owych wielkich królów lasów i równin, których Cooper [James Fenimore, autor Ostatniego Mohikanina - T.F.] tak uwielbiał ukazywać jako bohaterów. Nie możemy szczerze żałować ich eksterminacji, lecz trzeba przynajmniej oddać sprawiedliwość męskim cechom wykazywanym, zgodnie z ich wzorcami osobowymi i wykształceniem, przez dawnych amerykańskich Czerwonoskórych"48. Dwa tygodnie później, komentując masakrę w Wounded Knee, grzmiał: „Jak «Pioneer» już stwierdził, jedyna gwarancja naszego bezpieczeństwa jest całkowita eksterminacja Indian" 49 .

Historyk skądinąd zwalczający tezy Littlefielda sugeruje, że „baumowski «Pioneer», choć zdecydowanie prorepublikański, miał profil dość postępowy: redaktor naczelny zamieszczał w nim wyrazy poparcia dla ruchu wyzwolenia kobiet, alternatywnych religii, okultyzmu, tolerancji itd." ${ }^{50}$ Zrozumienie dla postulatów sufrażystek i zainteresowanie okultyzmem nie oznaczaja jednak poparcia dla populistów. Baum rzeczywiście nie odżegnywał się od teozofii, popularnego wówczas quasi-religijnego ruchu propagującego pozytywne myślenie jako drogę do zmian na lepsze, natomiast wciąż popularne oskarżenia, że Czarnoksiężnik propaguje masońską wizję świata, są rzecz jasna absurdalne ${ }^{51}$.

Czyżby więc poglądy polityczne Bauma uległy zmianie tuż przed 1900 r.? Bynajmniej. Po bankructwie „Pioneera” twórca krainy Oz przeniósł się z żoną do Chicago, gdzie przez kilka lat pracował dla gazety

${ }^{48}$ „Aberdeen Saturday Pioneer”, 20 XII 1890, cyt. za: A.W. Hastings, L. Frank Baum's Editorial on the Sioux Nations, http://www.history.ox.ac.uk/hsmt/courses_reading/undergraduate/authority_of_nature/week_7/baum.pdf (21 XI 2011).

${ }^{49}$ „Aberdeen Saturday Pioneer”, 3 I 1891, cyt. za: R. Venables, Twisted Footnote to Wounded Knee, „Northeast Indian Quarterly” Spring 1990, http://www.dickshovel. com/TwistedFootnote.html (21 XI 2011). W oryginale osobliwa literówka: „extirmination”. W 2006 r. potomkowie pisarza oficjalnie przeprosili Siuksów za krzywdy, jakie mogły wyrządzić te publikacje.

${ }^{50}$ D. Parker, dz. cyt., s. 55.

${ }^{51}$ W.R. Leach, The Clown from Syracuse. The Life and Times of L. Frank Baum, w: L.F. Baum, The Wonderful Wizard of Oz, Belmont 1991, s. 2. Ponieważ publikacje tych autorów - sa wśród nich również historycy, np. słynny z krucjaty przeciw New Age Dennis Cuddy - w Polsce są raczej niedostępne, tę ciekawą kwestię najlepiej śledzić w Internecie: http://ozandends.blogspot.com/2006/06/worldwide-conspiracies-in-oz.html (21 XI 2011), tamże odpowiednie linki. 
„Chicago Evening Post”. Latem 1896 r., w szczycie kampanii wyborczej, pismo to opublikowało jego wiersz, który warto przytoczyć w całości:

When McKinley gets the chair, boys,

There'll be a jollification

Throughout our happy nation

And contentment everywhere!

Great will be our satisfaction

When the „honest money” faction

Seats McKinley in the chair!

No more the ample crops of grain

That in our granaries have lain

Will seek a purchaser in vain

Or be at mercy of the „bull” or „bear”;

Our merchants won't be trembling

At the silverites' dissembling

When McKinley gets the chair!

When McKinley gets the chair, boys,

The magic word „protection”

Will banish all dejection

And free the workingman from every care;

We will gain the world's respect

When it knows our coin's „,correct”

And McKinley's in the chair!52

Jak widać, autora trudno nazwać zwolennikiem Bryana. Owszem, Czarnoksiężnik zdobył sobie na początku XX w. łatkę dzieła politycznie zaangażowanego, ale odpowiedzialny był za to wystawiony w 1902 r. na Broadwayu musical będący luźną adaptacją książki. Znalazło się w nim rzeczywiście sporo dowcipów i aluzji politycznych skierowanych do dorosłych, a krytykujących McKinleya i jego administrację (i nie tylko; pojawiał się tam np. John Rockefeller, dostarczający oleju do nasmarowania Blaszanego Drwala), tyle że większość z nich napisali sami adaptatorzy, a Baum zgodził się na przeróbki pod presja kontraktu ${ }^{53}$. Odżegnywał się też zawsze od przypisywania jego powieści jakichkolwiek alegorycznych znaczeń. Już sam wstęp do Czarnoksiężnika zawiera następujące zdanie: ,jedynym celem napisania opowieści o Czarnoksiężniku ze Szmaragdowego Grodu było zapewnienie rozrywki współczesnym dzieciom".

Gdy tylko Hearn opublikował swe rozważania, okazało się, że bardzo wielu naukowców ma wątpliwości co do alegorycznego charakteru Czarnoksiężnika. Ostatecznie twierdzenia Hearna wprowadził do

\footnotetext{
${ }^{52}$ „Chicago Times Herald”, 12 VII 1896, cyt. za: D. Parker, dz. cyt., s. 56.

${ }^{53}$ T.A. Ford, The Musical Fantasies of L. Frank Baum, Lake Worth 1969, passim.
} 
naukowego obiegu historyk David Parker w swoim artykule z 1994 r. ${ }^{54}$ $\mathrm{Z}$ alegorycznej interpretacji dzieła wycofywał się nawet Littlefield. Zaproszony w 1991 r. na zlot fanów krainy Oz, przyznał pod naciskiem zgromadzonych, że jego twierdzenia były bezpodstawne i powtórzył to publicznie w liście zamieszczonym w „New York Times” 7 II 1992 r. Jakiś czas później - niedługo przed śmiercia - opublikował w piśmie Międzynarodowego Klubu Fanów Czarnoksiężnika Oza, „Baum Bugle” artykuł, w którym twierdził, że całą interpretację stworzył dla zabawy, by ułatwić swoim uczniom z liceum przyswajanie historii, i nie spodziewał się tak poważnego jej potraktowania ${ }^{55}$. Pozostaje jednak zagadka, dlaczego zwlekał z tym wyznaniem ćwierć wieku.

Hugh Rockoff również przyznał się do błędu, ale tylko pośrednio. W 2002 r. ukazała się redagowana przez Ranjita Dighego książka The Historian's Wizard of Oz. Reading L. Frank Baum's Classic as a Political and Monetary Allegory, zbierająca wszystkie opublikowane od 1964 r. artykuły wraz z solidnym szkicem historycznym o populistach i komentarzem redaktora. Rockoff, raczej niezbyt zadowolony z wykazania bezsensowności jego „modelu”, napisał jednak w recenzji przytoczonej na okładce: „Praca ta pozostanie przez dłuższy czas ostatnim słowem w omawianej kwestii”.

Warto odnotować, że wielu badaczy powielało twierdzenia Littlefielda jeszcze długo po samokrytyce ich autora. Do takich należy np. Gretchen Ritter, która opublikowała w 1997 r. 30-stronicowy tekst powtarzający twierdzenia $\mathrm{z}$ wymienionych artykułów i dorzucający własne interpretacje, umieszczone też w jej - zmiażdżonej przez krytykę - książce poświęconej ruchowi antymonopolowemu w USA pod koniec XIX w. ${ }^{56}$ Już na ósmej stronie tej monografii można się dowiedzieć, że przeszkadzające bohaterom w przedostaniu się do krainy Kwadlingów plemię Głowomłotów symbolizuje „twardogłowych” polityków, którzy dla własnych celów próbuja skłócić mieszkańców stanów północnych i południowych, a stronę dalej autorka powtarza tezę, że „historia Skrzydlatych Małp odnosi się do ówczesnych wyobrażeń o amerykańskich autochtonach wygnanych z północnych lasów i poddanych na zachodzie autorytarnej władzy"57. Jeszcze dłużej promował tezy Littlefielda

${ }^{54}$ D. Parker, dz. cyt.

${ }^{55}$ H.M. Littlefield, The Wizard of Allegory, „Baum Bugle” 36, 1992, s. 24-25.

${ }^{56}$ G. Ritter, Silver Slippers and a Golden Cap. L. Frank Baum's The Wonderful Wizard of $\mathrm{Oz}$ and Historical Memory in American Politics, „Journal of American Studies" 31, 1997, nr 2, s. 171-203.

${ }^{57}$ Taż, Goldbugs and Greenbacks. The Anti-Monopoly Tradition and the Politics of Finance in America, 1865-1896, New York 1997, s. 8-9. 
i Rockoffa Victor Bascara, socjolog i politolog wykładający obecnie w Ośrodku Studiów Amerykańsko-Azjatyckich Uniwersytetu Kalifornijskiego, który odwoławszy się do nich w swoim artykule z 2000 r., sugerował, że Winkowie to nie Filipińczycy, lecz raczej chińscy imigranci w USA (dowodem następujące zdanie z Czarnoksiężnika: „Winkowie nie byli zbyt odważni, ale musieli słuchać rozkazów”, rozdz. 12). Bascara snuł przy tym długie rozważania w rodzaju: „Biorac pod uwage kontekst historyczny momentu i okoliczności ukazania się tej książki, możemy stwierdzić, że Czarnoksiężnik ze Szmaragdowego Grodu jest tekstem poświęconym amerykańskiemu imperializmowi. Choć nie jest to stwierdzenie nieścisłe, to jednak nieprecyzyjne. Dokładniej i bardziej użytecznie można określić go mianem tekstu antyimperialistycznego. W swym antyimperializmie książka ta nie wychodzi poza standardową argumentację antyimperialistów swojej epoki. Próbując pomnożyć szeregi zwolenników srebra, działacze antymonopolowi musieli wskazywać na związek między tworzeniem korporacji i trustów, nierównościami ekonomicznymi znanymi z życia codziennego oraz imperialnymi przygodami, które zdawały się pochłaniać obecnie rządzących, odciagając ich od innych problemów"58. W 2006 r. Bascara wydał książkę ojakżeby inaczej - imperializmie ${ }^{59}$, do której nie udało mi się dotrzeć, niemniej już ze streszczenia na okładce wynika, że jego poglądy nie uległy zmianie. Nie inaczej jest w wypadku Wojciecha Morawskiego, który w każdej kolejnej publikacji o historii gospodarczej świata (ostatnio w październiku 2008!) twierdzi, że Czarnoksiężnik to powieść z kluczem, wyrażająca obawy zwolenników srebra.

Wydaje się, że historia interpretacji Czarnoksiężnika ujawnia dwa smutne mechanizmy działajace w środowiskach naukowych. Pierwszym z nich jest gotowość do przyjmowania „prawd obiegowych” bez ich weryfikacji. Niekiedy nawet absurdalne tezy powtarzane przez kilku kolejnych badaczy jako „kontrowersyjny pogląd” stają się „poglądem godnym uwagi”, a w końcu „niezaprzeczalnie słuszną interpretacja”. Druga cecha, chyba nawet powszechniejsza, jest naginanie czytanego tekstu do własnej wizji i uporczywe trzymanie się swoich interpretacji. Parker, pisząc o atmosferze wytworzonej wokół tez Littlefielda w latach osiemdziesiątych, stwierdził: „Gdyby kogoś zmusić do wskazania jakiejś postaci, jakiegoś wydarzenia czy szczegółu realiów Czarnoksiężnika ze

${ }^{58}$ V. Bascara, Following the Money. Asian American Literature and the Preface to United States Imperialism, http://english.chass.ncsu.edu/jouvert/v4i3/bascar.htm (21 XI 2011), artykuł ukazał się w internetowym piśmie „Jouvert” poświęconym studiom postkolonialnym.

${ }^{59}$ Tenże, Model-Minority Imperialism, Minneapolis 2006. 
Szmaragdowego Grodu nieznajdującego wyjaśnienia w «populistycznej» interpretacji, miałby z tym ogromny problem"60. Przyczynił się do tego niewątpliwie „odruch stadny”, wśród naukowców wbrew pozorom częsty i uzasadniony tyleż lenistwem umysłowym, co i wiara w twierdzenia dostojnych starszych kolegów, a wreszcie niechęcią do narażenia się wyżej postawionym akademikom.

Cała sytuację dobrze podsumowuje, dotyczacy wprawdzie zupełnie innej sprawy, cytat z Kronik tygodniowych Antoniego Słonimskiego: „Pan Wyrzykowski w liście otwartym żali się, że pp. Schiller i Horzyca w długich z nim rozmowach wydobyli podstępem jemu tylko znany sens utworu Słowackiego Samuel Zborowski i teraz wystawiaja ten utwór i zagarną sami całą sławę komentatorów. Bardzo to musi być zawiły i trudny kawałek - ten Samuel Zborowski, jeśli jeden tylko na cała Polskę p. Wyrzykowski wiedział, o co tam chodzi. [...] Biedny Słowacki nie przypuszczał pewnie, że jeden Wyrzykowski tylko zrozumie jego dzieło, bo czyż warto było pisać dramat, który po stu latach jeden tylko, jedyny facet zrozumie? [...]. Ja sam ogłaszam przy okazji, iż w świeżo wydanej książce [...] nie zatrąciłem niczym o mistykę, religię ani uniwersalizm. Piszę to, choć wiem, że to nic nie pomoże. Jakiś przyszły Horzyca wyłudzi postępem od przyszłego Wyrzykowskiego prawdziwy, ale może nieznany sens i sekret tej książki”"61.

Tomasz Flasiński

The Wizard from the Land of the Dollar, or on the Interpretation of Sources (Summary)

A summary of a debate conducted in the 1970s-1990s and relating to an allegorical interpretation of L.F. Baum's The Wonderful Wizard of Oz. Created in 1964, this interpretation proclaimed that The Wizard could be an expanded parabola of a dispute preceding the election held in the U.S. in 1896 and dealing with the need for the existence of the silver dollar, supporting both its retention in circulation and William Jennings Bryan, the Democratic candidate who promoted this view. Although the notion in question was rather universally accepted among researchers and widely developed by their successors, it proved to be totally unfounded in sources, especially within the context of a biography of the book's author. Nonetheless, it still resounds in serious scientific publications.

Tomasz Flasiński - Instytut Historii PAN, e-mail: radagajs@poczta.fm

\footnotetext{
${ }^{60}$ D. Parker, dz. cyt., s. 53.

${ }^{61}$ A. Słonimski, Kroniki tygodniowe 1927-1931, Warszawa 2003, s. 10 („Kronika”, nr 3, 26 VI 1927).
} 